\title{
Research
}

\section{Communicating Ecology Through Art: What Scientists Think}

\author{
David J. Curtis $^{1}, \underline{\text { Nick Reid }}^{1}$, and Guy Ballard ${ }^{1}$
}

\begin{abstract}
Many environmental issues facing society demand considerable public investment to reverse. However, this investment will only arise if the general community is supportive, and community support is only likely if the issues are widely understood. Scientists often find it difficult to communicate with the general public. The role of the visual and performing arts is often overlooked in this regard, yet the arts have long communicated issues, influenced and educated people, and challenged dominant paradigms. To assess the response of professional ecologists to the role of the arts in communicating science, a series of constructed performances and exhibitions was integrated into the program of a national ecological conference over five days. At the conclusion of the conference, responses were sought from the assembled scientists and research students toward using the arts for expanding audiences to ecological science. Over half the delegates said that elements of the arts program provided a conducive atmosphere for receiving information, encouraged them to reflect on alternative ways to communicate science, and persuaded them that the arts have a role in helping people understand complex scientific concepts. A sizeable minority of delegates (24\%) said they would consider incorporating the arts in their extension or outreach efforts. Incorporating music, theatre, and dance into a scientific conference can have many effects on participants and audiences. The arts can synthesize and convey complex scientific information, promote new ways of looking at issues, touch people's emotions, and create a celebratory atmosphere, as was evident in this case study. In like manner, the visual and performing arts should be harnessed to help extend the increasingly unpalatable and urgent messages of global climate change science to a lay audience worldwide.
\end{abstract}

Key Words: art and environment, arts and society, environmental behavior, music, performance, scientific communication, social effects of the arts, sustainability

\section{INTRODUCTION}

Many environmental issues facing society, such as ecosystem collapse, demand considerable public investment to reverse. However, this investment will only arise if it is supported by the general community, and community support is only likely if the issues are widely understood (Miller 2004, Miller et al. 2006). The need for effective communication, public outreach, and education to increase support for collective action and behavior change is perhaps most pressing in the context of anthropogenic climate change (Moser and Dilling 2007). The role of the arts is often overlooked in extending scientific information and yet the role of the arts in communicating issues, influencing and educating people, and challenging dominant paradigms has a long tradition in the humanities (Belfiore and Bennett 2006). Throughout history artists have produced artworks that have attempted to jolt their communities out of complacency, articulate concerns about social justice and other issues, define and summarize debate, and provide enduring images that continue to inspire people down through the ages (Reichold and Graf 1998). Artists have a history of social activism (Gibson 2001, Belfiore and Bennett 2006, Jordaan 2008) and among the most pressing concerns of many contemporary artists is the deteriorating environment (Cembalest 1991, Goldberg 1991, de Groat 1994, Cless 1996, Kirn 2000, Branagan 2003a,b,c). The association between artists and those who attempt to conserve the natural environment has a long history (Bonyhady 2000), and many artists use their work to communicate important insights into human relationships with the natural environment (Pollak and MacNabb 2000, Williams 2001). Indeed, poets and writers, such as Henry David Thoreau in the USA and William Wordsworth in the UK, and visual artists have been influential in shaping attitudes toward landscape (Gold and Revill 2004). This has also been the case in Australia (Papadakis 1993, Curtis 2009) and there is growing recognition among practitioners of the role of the arts in facilitating societal transformation to environmental sustainability (Hawkes 2003, Mills and Brown 2004, Dieleman 2008, Kagan and Kirchberg 2008).

Artists are able to communicate with a large audience and their work has been used as an important component of protest movements against war, social injustice, poverty, AIDS, and Third World debt, and as part of the nonviolent, environmental protest movement (Doyle 2001, Branagan 2003a,b,c, Educational Broadcasting Corporation 2005, Jordaan 2008). In the USA, Underground Railway Theatre's eco-cabarets highlighted environmental issues (Sanders 1996) and Wes Sanders' eco-cabaret 'Beat the Heat' was an important part of the campaign to reduce greenhouse gas emissions and pollution in Vermont (C. Cevoli and W. Sanders, unpublished manuscript). In Australia, the photograph 'Rock Island Bend, Franklin River, Southwest Tasmania' by Peter Dombrovskis was used by The Wilderness Society in their successful campaign to prevent the damming of the Franklin River, and the photographs of Olegas Truchanas helped galvanize 
opposition to the flooding of Lake Pedder (Angus 1975, Dovers 1994, Kent 2010). Sirocco's performance of the 'Wetlands Suite' in the Macquarie Marshes highlighted the plight of a wetland system starved of water by irrigation and was broadcast to millions of viewers throughout the world (Bill O'Toole, personal communication).

A small number of contemporary scientists use the arts in a practical way to assist in their research, to gain insights that feed into their research, or to communicate their research to the general public. Nalini Nadkarni studies forest canopy biota and establishes connections with nonscientific audiences and artists for the purposes of heightening awareness of canopy ecology (Nadkarni 2004, 2007, 2008). Other scientists manage to merge an interest in aesthetics and science (e.g., Sullivan and McCrary 2002). Some UK and Australian scientific organizations have hosted artists in residence who have created works that were inspired by, or were a response to, science. Collaborations between science and art internationally include the Colorado EcoArts festival (www.ecoartsonline.org/ ); Art and Science Collaborations (www.asci.org/), Synapse (www.synapse.net.au/index.php), Gene(sis) project (Stern 2005), Orion (www.oriononline.org/), and Greenmuseum ( greenmuseum.org/). In Australia, such collaborations include the Australian Network for Art and Technology (www.anat.o rg.au/), and the Mildura Palimpsest (www.artsmildura.com.au/ old sites/palimpsest/pdfs/Palimpsest 5.pdf). Other direct interactions between ecology and the arts include the use of art to illustrate botanical and zoological texts (Hewson 1999, Olsen 2001).

The foregoing illustrates the potential for using the arts to communicate scientific information to a lay audience. Despite the range of collaborations between science and the arts internationally, only a tiny minority of scientists is involved and the environmental and sustainability literature is largely silent on the role of the arts in mass communicating science (e.g., Mercer 2000, Dodds and Middleton 2001, Goldie et al. 2005). This is reflected in higher education courses on sustainability. In a survey of 77 undergraduate and graduate environmental programs, none included the arts as an area of study (Sherrin 2008). This raises questions about why scientists do not use the arts more to communicate their results, whether they would consider using the arts, and, if so, in what roles.

To explore the responses of scientists to using the arts to expand audiences to ecological science, a series of constructed examples were performed for delegates over five days at an annual conference of the Ecological Society of Australia (ESA). The views of the conference attendees, which included research students as well as professional scientists, were surveyed at the end of the conference closing ceremony. The research explored the attitudes of ecological scientists and research students to the use of the arts for communicating scientific information.

\section{METHODS}

\section{Description of the event}

The 2003 ESA annual conference was held in Armidale, New South Wales, Australia in December of that year. The arts program was developed as a part of the conference to: (1) encourage scientists to reflect on alternative media to communicate their science to society; (2) provide a conducive environment for the delegates to receive information; (3) show scientists how the visual and performing arts may be used to aid understanding of complex scientific information, including synthesizing information and communicating ideas; (4) entertain, i.e., marvel at skills, enjoy something beautiful, laugh, relax, break monotony, affirm, and energize delegates; (5) aid conference logistics and processes; and (6) make the conference memorable by showcasing the depth and richness of Armidale's arts community.

Table 1 summarizes the components of the arts program, and the objectives of each component. The visual arts program included a specially commissioned conference image (Fig. 1), installations and art works summarizing various elements of the conference (Fig. 2), artists in residence (Fig. 3), especially commissioned conference mugs, and tours of the Armidale art galleries that featured exhibitions of ecological art. The performing arts program commenced with an opening ceremony that featured local Indigenous didgeridoo player Duan Pittman, the local dance group Body Moves, and the Armidale Sing NSW choir accompanied by the world-music folk band, Sirocco. All three performances were inspired by the Australian landscape and ecosystems, large images of which were screened behind the performers. At the conference barbeque, Duan Pittman told Indigenous ecological stories accompanied by didgeridoo. Eco-band, Tre Los Lantana, entertained delegates at the conference dinner with a cabaret show written for the event and that commented on some of the issues addressed at the conference.

Six theatrical performances were scattered throughout the conference as an alternative medium for communicating science, to emphasize various themes of the conference, and to entertain delegates. They featured the Armidale High School Performing Group. Their performances included virtuoso juggling and circus skills, physical skills, comedy, and dance. Rural tree dieback was explained through a juggling act, a piece of sketch comedy (Appendix 1), and street theatre (Digby Dieback Meets Theresa Green; Appendix 2). Landscape conservation planning was presented using narrative sketch theatre, and ecological balances and cycles were portrayed in An Ecological Circus (Figs. 4, 5, 6). Woodland decline and regeneration processes were theatricalized by changing an auditorium installation after each speaker to reflect the content of the papers in a symposium on the topic (Fig. 7). 
Fig. 1. As part of the arts program of the Ecological Society of Australia (ESA) conference, Armidale, 2003, this commissioned image by Anna Curtis, In the Balance, summarized the themes of the conference. The seed sprouting in the innermost circle represents new growth, the essence of life. The tiny seed represents a container of huge potential, whether plant or animal. The second circle represents the spiral of life; the force 'within us and beyond us, that which is the continuum of life.' The third circle represents Australian native fauna and includes the extinct gastric brooding frog, the endangered bilby and dugong, the echidna, possum, wombat, platypus, and flying fox. The fourth circle represents native flora and includes some of Australia's best known native flowers and fruits (Eucalyptus, Grevillea, Banksia, Acacia, Melaleuca, Callistemon, and Leptospermum). These four circles together represent the earth. The circle is 'womb like, protecting and nurturing.' The area surrounding the earth represents sky and ocean. Like embryonic fluid, it's a buffer zone. The birds and fish represent evolution, i.e., a sense of timelessness and continual change. The border incorporates changing landscapes caused by human interaction and intervention, including fire and regeneration, native grassland, woodland, wetlands, drought, erosion, salinity, insect attack, land clearing. The healthy rural setting includes biodiversity, greenbelts, tree planting, waterways, farming trees, crops, animals, and people. In her artist's statement the artist wrote: "To keep everything In the Balance, we must learn to work with nature, not against it. To respect the land, not abuse it. Through this artwork, I have attempted to communicate these concerns as well as creating an image that can be viewed on many levels. It is a meditative image, a mandala, a place to contemplate. What lies over the hill? What's hidden beyond the mountain? Will the new shoot grow into a giant tree or a bean stalk? The unknown holds a sense of hope for the future." Lino reduction print on paper, 30 x $30 \mathrm{~cm}, 2003$. See www.annacurtis.com.au/ for how the image was constructed (Copyright Anna Curtis).

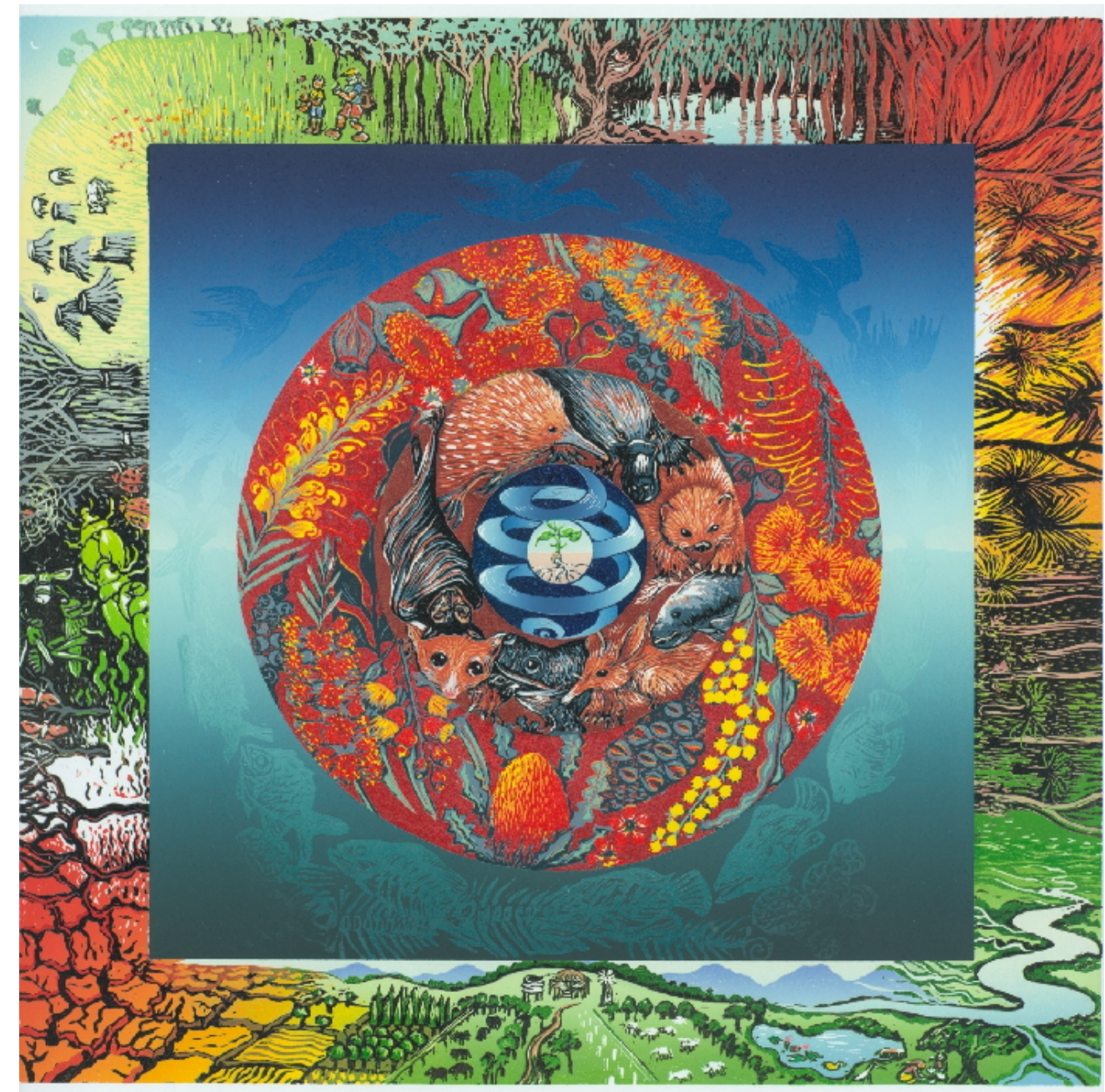


Table 1. Matrix of components of the arts program, and intended objectives: (1) encourage scientists to reflect on alternative media to communicate their science to society; (2) provide a conducive environment for the delegates to receive information; (3) show scientists how the visual and performing arts may be used to aid understanding of complex scientific information; (4) entertain; (5) aid conference logistics and processes; and (6) make the conference memorable by showcasing the depth and richness of Armidale's arts community. See text for further details.

\begin{tabular}{|c|c|c|c|c|c|c|}
\hline \multirow[b]{2}{*}{ Components of Arts Program } & \multicolumn{6}{|c|}{ Objectives } \\
\hline & 1 & 2 & 3 & 4 & 5 & 6 \\
\hline Opening & YES & YES & & YES & & YES \\
\hline Conference image & & YES & & & & YES \\
\hline Theatre group (symposia) & YES & YES & YES & YES & YES & YES \\
\hline Theatre group lunchtime & YES & & YES & YES & & YES \\
\hline Invited art works & YES & YES & YES & YES & & YES \\
\hline Artists in residence & YES & & & YES & & YES \\
\hline Installations in auditoria & & YES & YES & YES & & YES \\
\hline Outside artworks, flags etc. & & & & & YES & YES \\
\hline Circus/dance performance (BBQ) & YES & & YES & YES & & YES \\
\hline Indigenous performance (BBQ) & YES & & & YES & & \\
\hline Cabaret (conference dinner) & YES & & YES & YES & & YES \\
\hline Closing ceremony (An Ecological Circus) & YES & & YES & YES & YES & YES \\
\hline Art gallery tour & YES & & & YES & & YES \\
\hline
\end{tabular}

\section{Analysis}

The success of the arts program in achieving its objectives and the response of the delegates to the program were evaluated by means of an anonymous questionnaire conducted by the conference organizing committee at the end of the closing ceremony. Of the 500 delegates, 239 completed the questionnaire. The authors acted as participant observers in the conference (Ballard 2004). The archive of written material relating to the project and held by the authors includes minutes of meetings, correspondence, press clippings, project documentation, the delegate database, and a photographic and video record.

Fig. 2. One of the main Ecological Society of Australia (ESA) conference venues with artworks with an ecological theme from eight local artists: Stuart Boggs, Marty Branagan, Jenny Evelyn, Kerry Gulliver, Julia Hardman, Belinda Nano, Fay Porter, and Len Zell. Photo: David Curtis.

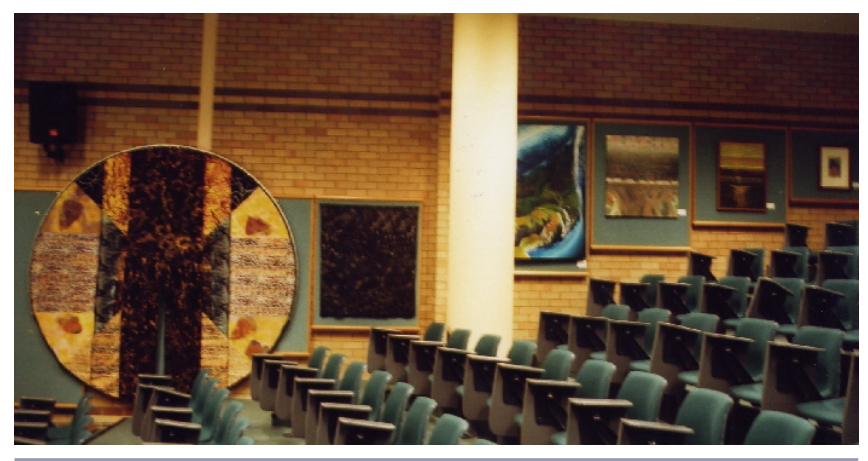

Fig. 3. Artists in residence, Jenny Evelyn (right), and Anna Curtis (left). Photo: David Curtis.

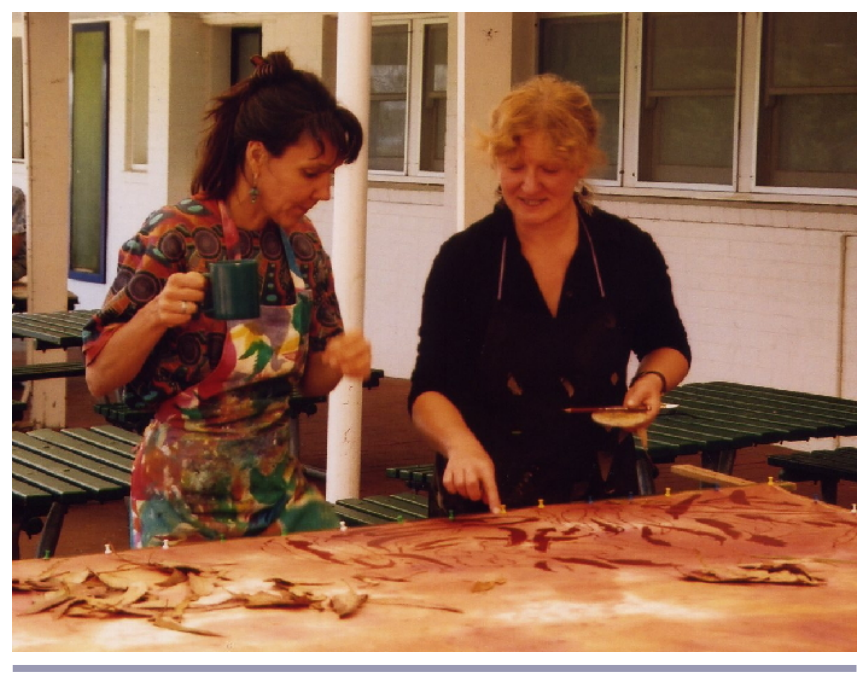

\section{RESULTS}

Of the 239 respondents to the questionnaire, about $80 \%$ were members of the ESA, half were professionals and the other half research students. Delegates' responses revealed that the arts program achieved most of its objectives (Tables 1,2). Eighty-six percent of respondents indicated that they found some parts of the arts program entertaining (Objective 4). Around $50 \%$ of respondents said that the arts program encouraged them to reflect on alternative ways to communicate science, helped provide a conducive environment to receive information, and assisted in conference 
Table 2. Results of the survey of attendees at the 2003 Ecological Society of Australia Conference, in Armidale, New South Wales ( $\mathrm{n}=239)$.

\begin{tabular}{|c|c|c|c|c|}
\hline & \multicolumn{4}{|c|}{ Percent response $(\%)$} \\
\hline & Yes & No & Unsure & No response \\
\hline $\begin{array}{l}\text { Did some elements of the arts program encourage you to reflect on alternative ways to } \\
\text { communicate science? }\end{array}$ & 55.2 & 31.8 & 10.5 & 2.5 \\
\hline $\begin{array}{l}\text { Did some elements of the arts program help to provide a conducive environment to receive } \\
\text { information? }\end{array}$ & 49.8 & 23.4 & 24.3 & 2.5 \\
\hline $\begin{array}{l}\text { Did some elements of the arts program convince you that the arts have a role in helping } \\
\text { people understand complex scientific information? }\end{array}$ & 51.5 & 29.7 & 16.3 & 2.5 \\
\hline Did you find some parts of the arts program entertaining? & 86.2 & 6.7 & 3.8 & 3.4 \\
\hline $\begin{array}{l}\text { Did some elements of the arts program assist in conference processes such as helping you to } \\
\text { identify the conference precinct? }\end{array}$ & 46.9 & 29.7 & 20.5 & 2.9 \\
\hline Would you consider using the arts in conjunction with your work in the future? & 23.9 & 53.6 & 18.4 & 4.2 \\
\hline
\end{tabular}

processes (Objectives 1, 2, and 5). About 50\% of respondents said that elements of the arts program convinced them that the arts have a role in helping people understand complex scientific information (Objective 2). It is assumed in the context of this survey and the arts program at the conference that the respondents will have interpreted 'helping people' to mean lay people or the general public. However, only $24 \%$ of respondents said that they would consider using the arts in conjunction with their work in the future (Table 2). The main

Fig. 4. Armidale High School Performing Group: from left to right Brendan Hatte, Ben Coleman, Angie Torbay, Vaughan Curtis, Rachel Goldsworthy, Robin Curtis. Photo: David Curtis.

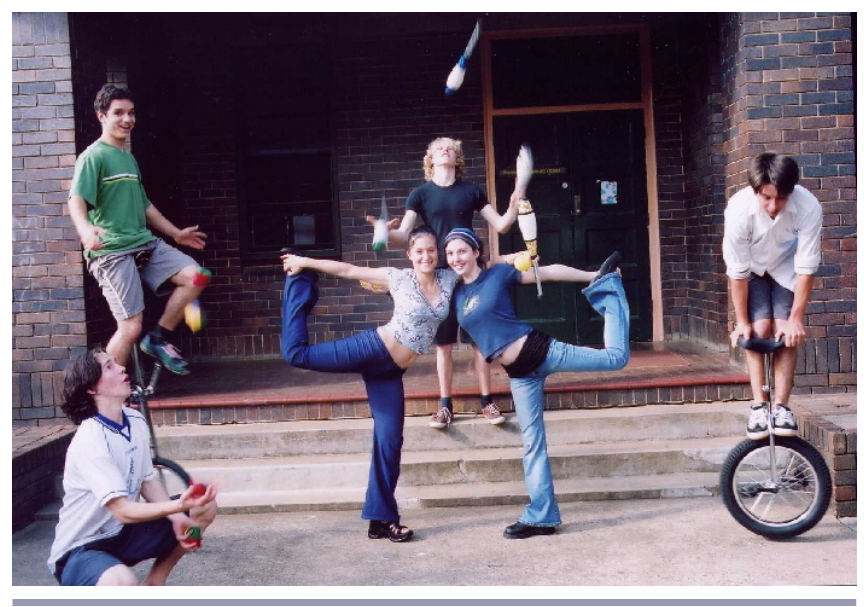

uses of the arts contemplated by delegates were to facilitate processes such as commanding people's attention, conveying key nonscientific information, providing an alternative communication medium, and aiding understanding of scientific information (Table 3). Most aspects of the arts program were favorably received, particularly the conference image, the various performances, and the artworks in the lecture theatres (Table 4). The aspect that conference-goers were least positive about was the conference dinner performance, probably because it was hard to hear because of poor acoustics at the venue (a large woolshed) and the large number of people, some of whom had to dine outside. As a result most attendees spent most of the evening talking over the noise.

Fig. 5. Armidale High School Performing Group as Barry Fay and Warren Streuth presenting a theatrical 'paper' in the symposium: 'Managing profitable and biodiverse production systems.' Photo: Laszlo Szabo.

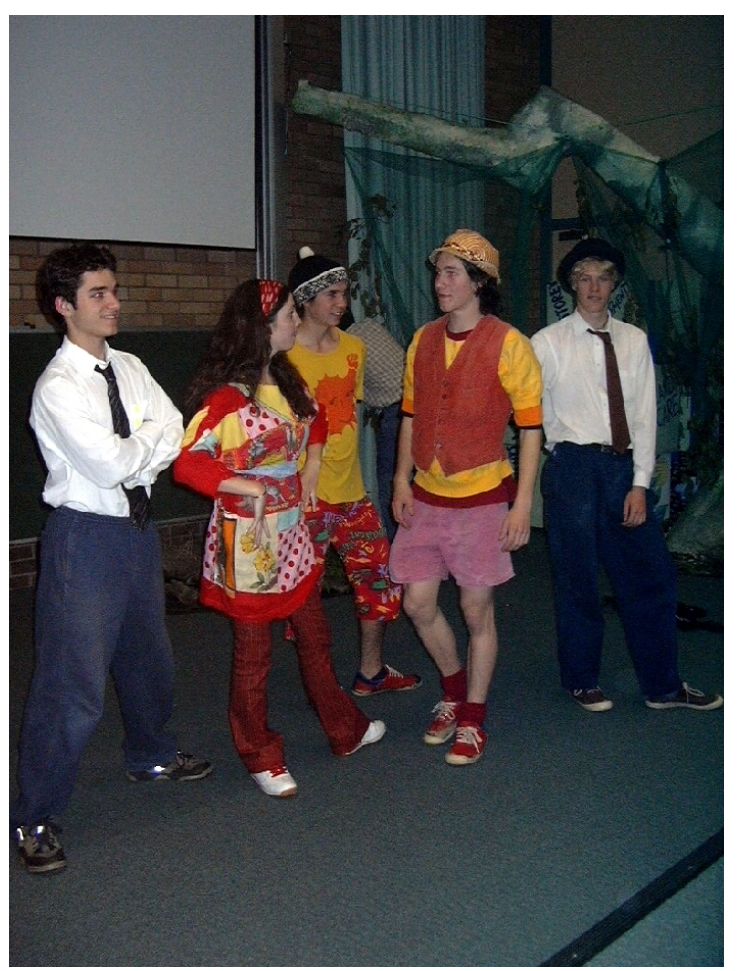


Table 3. Responses of people attending the 2003 Ecological Society of Australia Conference to the question: 'Would you consider using the arts in conjunction with your work in the future, [if yes] how might you do this?' $(\mathrm{n}=115)$.

\begin{tabular}{lc}
\hline \hline Method of using the arts & Percentage of respondents who chose this option \\
\hline As an alternative communication medium & 26 \\
To provide a conducive environment for receiving information & 18 \\
To aid understanding of scientific information & 24 \\
To entertain at a conference or in association with a presentation & 27 \\
To facilitate processes such as getting people's attention or conveying key & 28 \\
nonscientific information & 2 \\
None of these & 52 \\
No response & \\
\hline
\end{tabular}

\section{DISCUSSION}

Our results support the proposition that the arts have an important role in communicating scientific information. Over half the delegates said that elements of the arts program encouraged them to reflect on alternative ways to communicate science and convinced them that the arts have a role in helping people understand complex scientific information. Our results are consistent with the findings of the few researchers who have written about the use of the arts in communicating science (e.g., Lovett 2004, Nadkarni 2004, 2007, 2008). The social psychology literature emphasizes the importance of knowledge in shaping beliefs, attitudes, intention to act, and ultimately environmental behavior (Jackson 2005). Knowledge about an issue leads to an awareness of consequences, which is an important factor influencing proenvironmental behavior (Stern 2000). The view that the arts have a role in educating people has a long tradition in the humanities (Belfiore and Bennett 2006). Through communicating scientific and environmental knowledge the arts therefore appear to have a role in encouraging people to adopt proenvironmental behavior.

The case study highlighted several features of the arts that lend themselves to communicating science.

Fig. 6. Armidale High School Performing Group presenting An Ecological Circus in the closing ceremony of the conference. Photo: Laszlo Szabo.

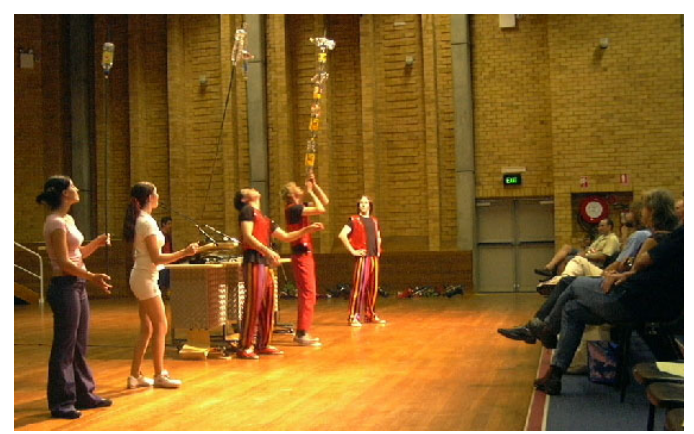

Fig. 7. Installation in a symposium about factors that were degrading or regenerating woodland ecosystems. The installation was altered between speakers to reflect the changes that ecologists spoke about (e.g., a decline in habitat led to loss of birds). Photo: David Curtis.

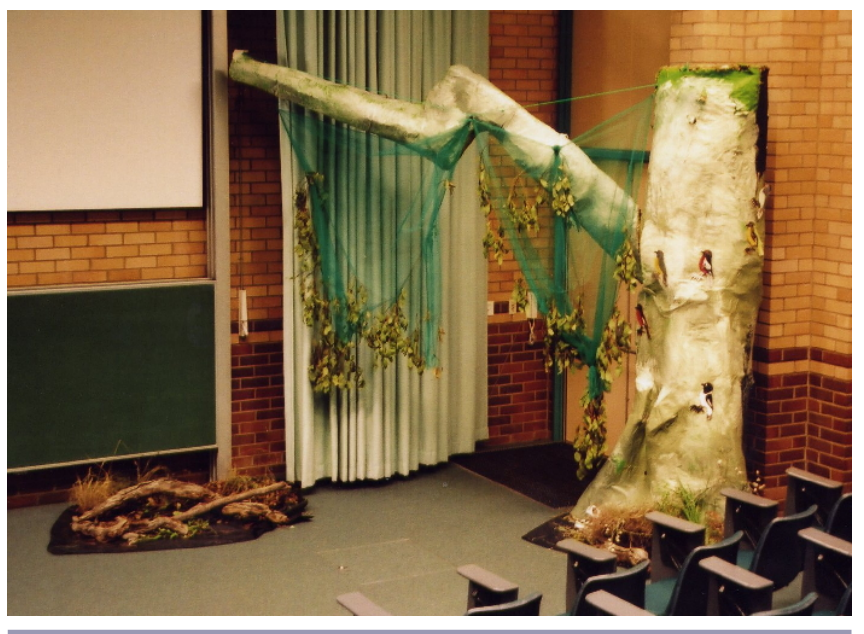

(1) Synthesizing and conveying complex scientific information

The capacity of both visual and performing arts to synthesize, simplify, and convey complex ecological or scientific ideas makes the information both more interesting and easier to remember. This feature is exemplified in the capacity of the visual arts to portray different landscape scenarios (e.g., Rob Youl, as cited in Campbell et al. 1988, Saunders and Hussey 1996, Salt and Lindenmayer 2004). Such features make the arts a valuable tool to raise awareness of particular issues. At the conference, the capacity of the arts to synthesize and convey complex information was exemplified by the conference image (Fig. 1) as well as several performances. For example, abstracts on woodland decline and restoration were converted into a comic piece of theatre that was presented as a 'paper' in a session on that topic (Appendix 1). Scientific research from over 20 years on rural eucalypt dieback was 
Table 4. Views of 2003 Ecological Society of Australia Conference attendees about different components of the arts program. Data are percentages of 239 respondents. 'Note: 'No response' or 'Unsure' responses generally indicated that delegates did not experience this component.

\begin{tabular}{|c|c|c|c|c|c|}
\hline & \multicolumn{5}{|c|}{ Percent response } \\
\hline & Positive & Neutral & Negative & Unsure $^{\dagger}$ & No response $^{\dagger}$ \\
\hline Conference image & 72.8 & 12.6 & 2.9 & 0.4 & 11.3 \\
\hline Conference opening & 68.2 & 11.7 & 2.5 & 4.2 & 13.4 \\
\hline Performance group & 63.2 & 16.3 & 4.2 & 3.8 & 12.6 \\
\hline BBQ & 53.1 & 18.8 & 4.2 & 11.3 & 12.6 \\
\hline Cabaret/conference dinner & 29.0 & 16.7 & 7.1 & 25.1 & 22.2 \\
\hline Art gallery tour & 3.4 & 6.3 & 1.3 & 59.0 & 30.1 \\
\hline Artworks in lecture theatres & 53.6 & 15.9 & 2.5 & 9.6 & 18.4 \\
\hline Closing performance & 42.3 & 2.5 & 0.0 & 13.0 & 42.3 \\
\hline
\end{tabular}

converted into entertaining street theatre (Appendix 2) and a virtuoso juggling act. Keynote abstracts were converted into the ecological circus that was performed in the final plenary session, including, for example, explanation of the nitrogen, water, and carbon cycles in a dramatic unicycle act, the juggling of conservation and productivity in a four-person club juggling act, and the balancing of ecosystem conservation and consumption in a balancing act (Fig. 6).

Delegates' acknowledgement of the ability of the visual and the performing arts to synthesize complex ideas and communicate them in an engaging form highlights the value of the arts in enhancing the teaching of scientific or environmental material and raising awareness about environmental issues in a wide range of contexts. Some practitioners have used them exactly in this way in Australia and overseas (D. J. Curtis, F. M. Curtis, I. McColm, J. Scrine, T. Blomfield, M. Howden, and I. Reeve, unpublished manuscript). Just as the visual and performing arts are used by the marketing industry to promote consumption, this study showed how they can be used to foster ecological sustainability. The responses of delegates showed that various art forms were viewed positively (Table 4). The main component that could have been improved was the performance at the conference dinner, which did not work particularly well because of the venue and background noise.

Scientists struggle to communicate their research to the general public (Moser and Dilling 2007, Cribb and Sari 2010), and often find that their academic arenas of professional practice do not encourage direct public engagement (Nadkarni 2008, Nadkarni and Stevenson 2009). This case study showed that ecologists recognize that the visual and performing arts are useful in communicating scientific information, over and above the traditional and widespread use of scientific illustration in taxonomy and biology publications, and in providing a conducive atmosphere in which to receive that information.

\section{(2) Promoting new ways of looking at issues}

The arts can give a voice to marginalized or silenced perspectives and thus play an emancipative social role and contribute to progressive political change (Alexander 2003, Belfiore and Bennett 2006). Socially critical art does this by synthesizing information, portraying new ways of looking at issues, and assisting public campaigns (Curtis 2012). Some of the performances in this case study contained elements of social criticism such as the opening photographic sequence, which was open to members of the public as well as conference delegates. The use of photography is an art form that has particular applicability in communicating ecological information and is rated highly by those involved in extension of scientific information to the public (Curtis 2011). This art form was therefore selected for the opening ceremony where evocative images of the Australian landscape were choreographed to music. The images depicted the variety of Australian ecosystems to familiarize overseas visitors to Australian landscapes, and allow Australian ecologists to feel pride in their natural ecosystems. The narrative of the imagery included jarring images of ecosystem degradation, a topic of the conference and the focus of the keynote presentations by members of the Wentworth Group of Concerned Scientists held immediately following the opening ceremony. Images of pollution, desertification, high-risk industries, and urban sprawl toward the end of the opening ceremony were intended to shock the audience and raise concerns about the ecosystems vulnerable to climate change and other threatening processes.

\section{(3) Touching peoples' emotions}

One of the attributes of the arts is their ability to evoke emotions. Emotions are physiological responses to particular types of sensory experiences (Atkinson et al. 1990). The performances at the conference were designed to be emotive. Emotional responses included happiness, manifested by tears of joy and laughter, indignation, surprise, pride, and catharsis (in the final circus performance). The standing ovation for the final performance and some respondents' unsolicited comments suggested that they were moved deeply by different 
elements of the arts program. When people become emotional, they tend to pay more attention to events and as a consequence commit the experience to long-term memory (Atkinson et al. 1990). Emotions are an important influence on environmental behavior in Triandis' Theory of Interpersonal Behaviour (Jackson 2005). Kollmuss and Agyeman (2002) point out that the emotions of fear, sadness, and anger evoked by environmental degradation can encourage proenvironmental behaviors, although in some people, emotional distancing or denial can also enable a degree of comfortable inaction. Thus, through evoking an emotional response, the arts may aid memory and analysis of the subject of the artistic work.

\section{(4) Creating a celebratory atmosphere}

The ability of the arts to create memorable moments and a celebratory atmosphere was evident at the conference. The conference itself could be viewed perhaps as a 'celebrationist event,' that is, an event that by emphasizing beauty and wonder of the natural environment celebrates the natural environment and incorporates many art forms (Curtis 2007). We theorize that a conference can function to a degree as a celebrationist event by providing: (1) 'neutral ground' for discussion of contentious issues; (2) a 'suspension of normality,' i.e., a break in normal day-to-day life; (3) 'liminality,' i.e., a condition of psychological ambiguity in which basic ideas and mental constructs of identity and society are broken down or weakened and can be reworked (Meekison and Higgs 1998); and (4) 'communitas,' that is, the shared or collective experience of the symbolic or liminal (Turner 1982). Although many ESA conference-goers would eschew this characterization of their national ecological conference in favor of the paradigm of the 'objective science meeting,' ecological conferences share many of the characteristics of a celebrationist event.

Some of the art forms exhibited at this conference celebrated the natural environment, e.g., the conference image, the art exhibition, the photographic images, and the performances by Sirocco, the children's choir, the dancers, and the Indigenous story teller and didgeridoo player. However, did the scientific component of this conference celebrate the natural environment? It is possible to infer from the tone and tenor of papers presented at such a conference that ecologists feel, at the very least, a warm regard for the ecosystems they investigate. The scientific discourse usually avoids displays of emotion but people working in the natural resources sector often feel a strong emotional bond to the natural environment (Curtis 2011). Because of this, one may infer that the scientific work presented at an ecological conference perhaps unintentionally celebrates the natural environment. Given this, the integration of performances and visual arts are likely to be especially useful in re-energizing those with a strong ecocentric ethos because of the deliberative capacity of the arts to move people emotionally.

The arts program at ESA 2003 provided a dimension that is normally lacking in scientific conferences. Years later, people still remark unprompted to the authors that the conference was 'special.' Many people working in ecology or the environment spend a lot of time working on depressing issues, e.g., biodiversity decline or climate change. The arts have a role in uplifting the spirits and reinvigorating people, and the standing ovation for the final performance of the conference ( $A n$ Ecological Circus) is perhaps evidence that the arts program at ESA 2003 performed this function.

Scientists acknowledge the potential of the arts in communicating science but appear to be held back from using them. In this study, $86 \%$ of ecologists and research students responded favorably to the use of the arts in a scientific forum, over half saw their potential in communicating science, but only $24 \%$ would consider using them. This begs the question why so few scientists are willing to communicate their science through the visual and performing arts? This is an important area for further research given that humanity will have to use all means at its disposal in the 21st century to convince a skeptical society of the importance of transforming the dominant development model of run-away consumption to one of the sustainable global village.

\section{CONCLUSION}

Scientists struggle to communicate their research to the general public, and often find that their academic arenas of professional practice do not encourage direct public engagement. This case study showed that ecologists respond favorably to the use of the arts in a scientific forum and recognize that the visual and performing arts are useful in communicating scientific information and providing a conducive atmosphere in which to receive that information. The literature reveals the dramatic role of the arts in communicating issues, influencing and educating people and challenging dominant paradigms. Despite acknowledging the potential of the arts in communicating science, few scientists merge science with the arts. There is, therefore, considerable scope to grow this area of endeavor and, potentially, have a huge impact on public attitudes. In an era when skeptics threaten to undermine a scientific view of major environmental concerns such as climate change (Mooney 2007), the use of the arts to connect with people emotionally may indeed be an effective way to win support for actions to reverse problems like anthropogenic climate change and deserves further research effort.

Responses to this article can be read online at: http://www.ecologyandsociety.org/vol17/iss2/art3/responses/

\section{Acknowledgments:}

A sincere thanks to all those artists and performers who participated in the arts program for the 2003 Ecological Society of Australia Conference, to those who participated in 
surveys, and to those who gave permission for the use of their images. Thanks to Land and Water Australia and the Rural Industries Research and Development Corporation for funding for this research. Thanks to Ian Reeve (Institute of Rural Futures, University of New England, Armidale NSW) for advice on the analysis of the project and to Laszlo Szabo and Anna Curtis for the use of images.

\section{LITERATURE CITED}

Alexander, V. D. 2003. Sociology of the arts: exploring fine and popular forms. Blackwell Publishing, Malden, Massachusetts, USA.

Angus, M. 1975. The world of Olegas Truchanas. The Olegas Truchanas Publication Committee, Hobart, Tasmania, Australia.

Atkinson, R. L., R. C. Atkinson, E. E. Smith, D. J. Bem, and E. R. Hilgard. 1990. Introduction to psychology. Harcourt Brace Jovanovich, Orlando, Florida, USA.

Ballard, G. 2004. ESA Ecology 2003 Armidale conference: feedback from delegates. Bulletin of the Ecological Society of Australia 34(1):8.

Belfiore, E., and O. Bennett. 2006. Rethinking the social impact of the arts: a critical-historical review. Centre of Cultural Policy, University of Warwick, Coventry, UK.

Bonyhady, T. 2000. The colonial earth. Melbourne University Press, Carlton South, Victoria, Australia.

Branagan, M. 2003a. The art of nonviolent activism. Social Alternatives 22(3):50-55.

Branagan, M. 2003b. The $\operatorname{art}(\mathrm{s})$ of protest in Australia: 1982-2002. Dissent 11:36-40.

Branagan, M. 2003c. Environmental education, activism and the arts. Convergence 38(4):33-50.

Campbell, R., R. Chandler, and G. Thomas. 1988. Victoria felix: improving rural land with trees. Monash University, Clayton, Australia.

Cembalest, R. 1991. The ecological art explosion. ARTnews 90(6):96-105.

Cless, D. 1996. Eco-theatre, USA: the grassroots is greener. The Drama Review 40(2):79-102. http://dx.doi.org/10.2307/1 146531

Cribb, J., and T. Sari. 2010. Open science: sharing knowledge in the global century. CSIRO Publishing, Collingwood, Victoria, Australia.

Curtis, D. J. 2007. Creating inspiration: how visual and performing arts shape environmental behaviour. Dissertation, University of New England, Armidale, New South Wales, Australia.
Curtis, D. J. 2009. Creating inspiration: the role of the arts in creating empathy for ecological restoration. Ecological Management \& Restoration 10(3):174-184. http://dx.doi.org/ 10.1111/j.1442-8903.2009.00487.x

Curtis, D. J. 2011. Using the arts to raise awareness and communicate environmental information in the extension context. Journal of Agricultural Education and Extension 17 (2):181-194. http://dx.doi.org/10.1080/1389224X.2011.544458

Curtis, D. J. 2012. Articulating a critical voice: artists who 'rattle the cage' about the environment. Chapter 20 in S. Bingham, editor. The art of social critique: painting mirrors of social life. Rowman \& Littlefield, Lanham, Maryland, USA.

Curtis, D. J., F. M. Curtis, I. McColm, J. Scrine, T. Blomfield, M. Howden, and I. Reeve. 2010. Using drama in environmental education: Australia and Canada. VII World Congress of IDEA 2010 Live, Living Diversity, Live! Embracing the Arts of Transformation! Belém, Brazil, 17-25 July.

de Groat, G. 1994. Artists and the environment: a report from the 81st College Art Association Conference in Seattle. Electronic Green Journal 1(1). [online] URL: http://escholars hip.org/uc/item/50r7n1c7

Dieleman, H. 2008. Sustainability, art and reflexivity: why artists and designers may become key change agents in sustainability. Pages 108-146 in S. Kagan and V. Kirchberg, editors. Sustainability: a new frontier for the arts and cultures. Verlag fur Akademische Schriften, Frankfurt, Germany.

Dodds, F., and T. Middleton, editors. 2001. Earth summit 2002: a new deal. Earthscan, London, UK.

Dovers, S. 1994. Australian environmental history: essays and cases. Oxford University Press, Melbourne, Victoria, Australia.

Doyle, T. 2001. Green power: the environmental movement in Australia. University of New South Wales Press, Sydney, New South Wales, Australia.

Educational Broadcasting Corporation. 2005. Get up, stand up: the story of pop and protest. Educational Broadcasting Corporation, New York, New York, USA. [online] URL: $\underline{\text { ht }}$ p://www.pbs.org/wnet/getupstandup/

Gibson, L. 2001. The uses of art: constructing Australian identities. University of Queensland Press, St Lucia, Queensland, Australia.

Gold, J. R., and G. Revill. 2004. Representing the environment. Routledge, London, UK. 
Goldberg, V. 1991. A terrible beauty. ARTnews 90 (6):106-113.

Goldie, J., B. Douglas, and B. Furnass. 2005. In search of sustainability. CSIRO Publishing, Collingwood, Victoria, Australia.

Hawkes, J. 2003. The fourth pillar of sustainability: culture's essential role in public planning. Common Ground Publishing, Champaign, Illinois, USA.

Hewson, H. 1999. Australia: 300 years of botanical illustration. CSIRO Publishing, Collingwood, Victoria, Australia.

Jackson, T. 2005. Motivating sustainable consumption: a review of evidence on consumer behaviour and behavioural change. University of Surrey, Guildford, UK.

Jordaan, J. 2008. Art, advocacy, and social development: designing and implementing art-based human rights advocacy campaigns at the organisation of art for humanity. Pages 290-319 in S. Kagan and V. Kirchberg, editors. Sustainability: a new frontier for the arts and cultures. Verlag fur Akademische Schriften, Frankfurt, Germany.

Kagan, S., and V. Kirchberg, editors. 2008. Sustainability: a new frontier for the arts and cultures. Verlag fur Akademische Schriften, Frankfurt, Germany.

Kent, R. 2010. In the balance: art for a changing world. Museum of Contemporary Art, Sydney, New South Wales, Australia.

Kirn, M. 2000. They shoot puppets, don't they? The state of eco-art. Arts Paper 3(2):1-2.

Kollmuss, A., and J. Agyeman. 2002. Mind the gap: why do people act environmentally and what are the barriers to proenvironmental behaviour. Environmental Education Research 8(3):239-260. http://dx.doi.org/10.1080/13504620220145401

Lovett, S. 2004. Capacity building and knowledge exchange methods for community-based river and riparian management. Final Report SIW4 - Canadian Travelling Fellowship, Lovett Clarke Consulting, Canberra, Australian Capital Territory, Australia.

Meekison, L., and E. Higgs. 1998. The rites of spring (and other seasons): the ritualising of restoration. Restoration and Management Notes 16(1):73-81.

Mercer, D. 2000. A question of balance: natural resources conflict issues in Australia. Federation Press, Annandale, New South Wales, Australia.

Miller, J. D. 2004. Public understanding of, and attitudes toward, scientific research: what we know and what we need to know. Public Understanding of Science 13:273-294. http:/ /dx.doi.org/10.1177/0963662504044908
Miller, J. D., E. Augenbraun, J. Schulhof, and L. G. Kimme. 2006. Adult science learning from local television newscasts. Science Communication 28:216-242. http://dx.doi.org/10.117 7/1075547006294461

Mills, D., and P. Brown. 2004. Art and wellbeing. Australia Council for the Arts, Strawberry Hills, New South Wales, Australia.

Mooney, C. 2007. Spreading the word. Sydney Morning Herald, 26 April.

Moser, S. C., and L. Dilling. 2007. Creating a climate for change: communicating climate change andfacilitating social change. Cambridge University Press, Cambridge, UK. http:// dx.doi.org/10.1017/CBO9780511535871

Nadkarni, N. 2004. Not preaching to the choir: communicating the importance of forest conservation to nontraditional audiences. Conservation Biology 18:602-606. http://dx.doi.or $\mathrm{g} / 10.1111 / \mathrm{j} .1523-1739.2004 .01832 . \mathrm{x}$

Nadkarni, N. 2007. Portrait of the artist as a young sapling: trees as artists and mobile entities. Science Creative Quarterly Jan-March (2):1-5.

Nadkarni, N. 2008. Between earth and sky: our intimate connections with trees. University of California Press, Berkeley, California, USA.

Nadkarni, N., and R. Stevenson. 2009. Summary of symposium: linking scientists with non-traditional public audiences to enhance ecological thought. Symposium 9 ESA meeting, August 5, 2008. Bulletin of the Ecological Society of America 90(1):134-137.

Olsen, P. 2001. Feather and brush: three centuries of Australian bird art. CSIRO Publishing, Collingwood, Victoria, Australia.

Papadakis, E. 1993. Politics and the environment: the Australian experience. Allen and Unwin, St. Leonards, New South Wales, Australia.

Pollak, M., and M. MacNabb. 2000. Hearts and minds: creative Australians and the environment. Hale and Iremonger, Alexandra, New South Wales, Australia.

Reichold, K., and B. Graf. 1998. Paintings that changed the world: from Lascaux to Picasso. Prestel, Munich, Germany.

Salt, D., and D. Lindenmayer. 2004. Trees and biodiversity. Rural Industries Research and Development Corporation, Canberra, Australian Capital Territory, Australia.

Sanders, W. 1996. The making of InTOXICating: an Ecocabaret. Orion Autumn:12-16.

Saunders, D., and P. Hussey. 1996. Creating a Hans Heysen: painting saline lands into a nature conservation picture. Australian Journal of Soil and Water Conservation 9:15-19. 
Sherrin, K. 2008. Higher environmental education: core disciplines and the transition to sustainability. Australian Journal of Environmental Management 15:189-195.

Stern, L. E. 2005. The Gene(sis) project: a laboratory for artsbased civic dialogue. Case study: Henry Art Gallery. Animating Democracy, American for the Arts, Washington, D.C., USA. [online] URL: http://www.americansforthearts.org/ animatingdemocracy/pdf/labs/henry art gallery case study. pdf

Stern, P. C. 2000. New environmental theories: toward a coherent theory of environmentally significant behavior. Journal of Social Issues 56(3):407-424. http://dx.doi.org/10.1 $\underline{111 / 0022-4537.00175}$

Sullivan, A., and A. B. McCrary. 2002. Mudflat: the aesthetics of a marine biologist's engagement with her work. Curriculum Inquiry 32(3):357-365. http://dx.doi.org/10.1111/1467-873X .00235

Turner, V. 1982. From ritual to theatre: the human seriousness of play. Performing Arts Journal Publications, New York, New York, USA.

Williams, J. 2001. Using art to communicate science. Bulletin of the Ecological Society of Australia 31(3):2-3. 
APPENDIX 1. Part of script for symposium 'Linking Policy, Research and Practice: Getting nature back into productive landscapes'. (Author:David Curtis).

BARRY, FAY and WARREN enter

WARREN: Look mum and dad - nary a bird to be heard.

FAY: No Warren - I think they've all gone off to the ornithologist's conference.

BARRY: Was that the ornithologist joke Fay?

FAY: Yes Barry.

BARRY: I've got a better one - wanna hear it? 'What's that large flightless Australian bird?' 'e mused.

FAY: 'You don't mean the one from Northern Queensland and New Guinea?' said Caso warily.

GROAN sign

WARREN: It's dreadful mum and dad - all those lovely native plants and animals gone - right down to the coprophagous moths.

BARRY: Streuth, what on earth are they Warren?

WARREN: Well dad, coprophagous moths lay their eggs in the dung of koalas. When they hatch out they devour the digested eucalyptus leaves in the dung - the ultimate adaptation - eaters of ...

BARRY: That's enough of that kind of language around here boy! This is a 
scientific conference! (hits WARREN)

WARREN: (On the ground studying something) Not to mention all those endozoochorous grasses mum and dad.

FAY: What are they dear?

BARRY: I've got a gut feeling about this.

WARREN: Funny you should say that dad, because endozoochory is the dispersal of seeds via animal guts ...

BARRY and FAY stare blankly

WARREN: You know, in the dung. Did you know some grasses like Lachnagrostis filiformis are actually spread in the dung of kangaroos and sheep?

BARRY: I don't necessarily feel all that enriched with that bit of exciting information Warren ...

WARREN: Anyway they're all gone!! (wails) 
APPENDIX 2. Abridged script of 'Digby Dieback versus Theresa Green'. (Author: David Curtis).

Street Theatre. Boxing ring set.

SPRUIKER: Good afternoon ladies and gentlemen. Prepare for the greatest boxing tournament of all time ... Meet our reigning champion, Digby Dieback, or otherwise known as Rambo Ringbarkus III, junior. He's taken on all comers. Rambo's obliterated the oaks of England. He's cut the kauris of Kiwiland and felled the forests of Finland. Yes, Rambo Ringbarkus is a big Forest Fella!

Now he's here. So watch out, he'll ringbark our redgums and batter our Aussie boxes. He's out of the box this boy, and he'll batter our yellow boxes, our grey boxes, and fuzzy boxes, black boxes, apple boxes -

[RAMBO picks up box]

And cardboard boxes.

[GROAN]

Who'll take this boy on? ...

THERESA

GREEN: I will, I will, I will.

SPRUIKER: An opponent for Digby Dieback ... Give this brave soul a hand. And what's your name my fine friend?

THERESA: Theresa.

SPRUIKER: Theresa? That's a nice name, Theresa who?

THERESA: Theresa Green.

[GROAN]

SPRUIKER: And I see you're well prepared - brought your own first aid kit for the inevitable knockout. You can see what you're up against - don't want to reconsider?

THERESA: Look, I may look a bit green, but I've branches all around the countryside.

[SPRUIKER - pick up gloves] 
SPRUIKER: Sounds suspiciously like a Landcare joke - give Theresa a cheer ... Prepare for Round 1 and come out fighting.

\section{[Theresa lands punch]}

SPRUIKER: Theresa's planted a powerful pauciflora punch right to the centre of Rambo's recharge area. But look, Rambo's retaliating with a rain of Xmas beetles to the head ...

\section{[THERESA is shaken]}

Theresa's shaken, she's shocked. But no, she's shrugged it off and is shunting in strongly ... Bop - with a brave banksia. Wappo - with a wonderful wattle ... But to no avail. Rambo knocks her blows back with mistletoe, beetles, bugs, hares, rabbits, sheep and finally one gigantic Stihl 50 SL 65 GP x 2000 chainsaw.

[RAMBO comes on with chain saw going (with chain removed)]

And she's out! Theresa is down for the count. No, she's up - and what's this? She's brought her bandage with her. What's this, Theresa Green - time for some remedial repair work?

THERESA: This is my secret weapon - he hasn't a chance against my shelterbelt!

SPRUIKER: And she's wrapping up his recharge area with a long shelterbelt; a nice row of snowgums and silver wattles ... on the upper areas ... forming a system of corridors and networks!

THERESA: As you can see, I have got him under the spell of my ecological thresholds.

SPRUIKER: She's got him staggering. There's no band-aid half measures here! And now she's fenced off his last remnant of native vegetation and is managing it as a separate land unit! ... And he's helpless before her onslaught of remedial repair work ... Re-afforesting the recharge area with woodlots ... and reintroduced gamma diversity!

And Rambo's teetering. He's going, he's going, he's gone.

Folks, it's a knockout in the first round. Put your hands together for the new Landcare Champion - Theresa Green!! 